\title{
The Determination and Enforcement of Jus Cogens Norms For Effective Human Rights Protection
}

\author{
Alfred Mwenedata ${ }^{1} \&$ Joseph Sehorana
}

\begin{abstract}
This research paper is focused on the issue of peremptory norms (jus cogens), formulated in the 1969 Vienna Convention on the Law of Treaties, and its applicability in core Human Rights implementation. It thus examines the nature of jus cogens and its formation vis-à-vis Human Rights and advocates for the additional value that jus cogens can bring to core Human Rights implementation. The focal problem that the research addresses is the lack of clarity attached to jus cogens and its subsequent effects on effective core Human Rights implementation. To wonder why jus cogens remains ineffective and to see what can be done, and by whom, to enhance its impact on core Human Rights is the main goal of this study. The authors firmly believe that the jus cogens concept brings a significant contribution to core Human Rights implementation, putting them at the foundation of the international legal order. This effect is substantial to the future core Human Rights development, but, depends also on the future redefinition of jus cogens itself.
\end{abstract}

Index words: Jus cogens norms, human rights, international law, enforcement, determination, international court of justice, convention, protection, recognition, admissibility, states, United Nations, judicial review, universajurisdiction.

\section{GENERAL INTRODUCTION}

\section{THE RATIONALE TO THE STUDY}

Nowadays, humanity is cruelly afflicted by serious violations of Human Rights including peremptory Human Rights which were regarded as jus cogens or the most sacred. This situation pushed the researchers to meditate on the effectiveness of the concept of jus cogens and its impact on Human Rights. Indeed, the reality is that there is so much in common between Human Rights and jus cogens norms. But it is also clear that jus cogens cannot cover every Human Right. Thus, there is an issue to determine which Human Rights would have a jus cogens character. This is not an easy duty as the concept of jus cogens itself is imprecise. Therefore, we can precise that the prevailing problem which this study attempts to address is the vagueness of the concept of jus cogens and subsequently its inefficiency in the context of Human Rights protection.

Through the course of elaboration of the significance of jus cogens, it was stated several times that determining which rules are to be regarded as jus cogens is not an easy task. Although scholarly writing and legal doctrine have given a prominent contribution to this issue, jus cogens norms can only be defined by Courts in order to have the procedural effect that we find so significant for Human Rights implementation. The remaining issue at this point is to know exactly the competent Court to define and enforce jus cogens. In our humble view, as the principal judicial organ of Public International Law, the International Court of Justice is inevitably called upon to highlight the fundamental values that the international community has expressed. Its jurisprudence is an essential contribution since it specifies the content of the basic principles of Public International Law, including jus cogens. However, at the time when violations of jus cogens multiply, many informed observers question themselves about the contribution of the International Court of Justice in determining and enforcing these norms and how this role is materialized through its jurisprudence. They are consequently wondering whether the contemporary manipulations of peremptory Human Rights would not be one of the consequences of their indefiniteness. Accordingly, this study attempts to address this crucial issue about the contemporary manipulations of peremptory Human Rights by relating it to the vagueness of the concept of jus cogens itself.

\section{PROBLEM STATEMENT}

The violations of Human Rights exist in every part of the world. For example, Amnesty International's 2014 World Report shows that "individuals are tortured in at least 81 countries". ${ }^{2}$ While some gains have been

\footnotetext{
${ }^{1}$ Dr. Alfred MWENEDATA is a researcher and lecturer in law at University of Kigali (UoK).

2 Amnesty International, "Report 2009: the State of the World's Human Rights", in Amnesty International Publications, 2009, p. 4. 
made over the course of the last six decades, "Human Rights violations still plague the world today". 3 In the early twentieth century itself, the world faced a number of atrocities such as the genocide against Tutsi in Rwanda, killings in DRC, Central African Republic, Libya, Somalia, Egypt, Syria; rape committed on minor children, and many more. What is more surprising is that even the most "sacred" Human Rights (jus cogens) are violated. Facing this situation, one could ask if peremptory Human Rights are real or utopia. It would be more precise to say that this question is a background inquiry necessary for the topical question to know if the notion of jus cogens, as actually defined and understood can give Human Rights enforcement a real perspective.

This research paper attempts to focus on such issues around jus cogens and its applicability in core Human Rights implementation. The focal problem that the research addresses is the lack of clarity attached to jus cogens and its subsequent effects on effective core Human Rights enforcement. The researchers wonders why jus cogens remains ineffective and attempts to see what can be done (and by whom) to enhance its impact on core Human Rights. The overall question of the research study can be formulated as follows: What is the extent of the concept of jus cogens in respect to core Human Rights from the perspective of International Law? The partial issues and theoretical concerns that the research focuses on can be formulated in several questions such as:

- What are the consequences of the perplexing character of the jus cogens on the effective protection of Human Rights?

- How and by whom the jus cogens should be determined and enforced?

\section{HYPOTHESES}

The main hypothesis is that jus cogens should give core Human Rights legal universality necessary for their enforcement, but this role is denigrated by the mystifying character of the concept in lack of a fixed extent and meaning. This foremost premise is supplemented by these subsequent hypotheses:

- The mystifying character of jus cogens causes its depreciation and deficiencies in protecting core Human Rights;

- The concept of jus cogens should be defined and enforced by the ICJ through its jurisprudence.

\section{RESEARCH OBJECTIVES}

The main objective of this study is to provide a detailed analysis of the extent of the concept of jus cogens in respect to core Human Rights from the perspective of International Law. This leading objective is supplemented by these aims:

- to reveal the consequences of the confusing character of the concept of jus cogens in the protection of core Human Rights;

- to elucidate the role of ICJ in the determination and enforcement of jus cogens.

\section{CHAPTER I: CONCEPTUAL AND THEORETICAL FRAMEWORK}

The overall goals of this chapter are firstly to establish the significance of the general field of study, and then identify a place where a new contribution could be made. The main part of the chapter is on clarifying key concepts related to the study and reviewing existing literature on jus cogens and Human Rights protection. Therefore, in the first section, two concepts will be discussed: "jus cogens", and "Human Rights". The subsequent part will explore the dominant themes of the research questions: the extent of the concept of jus cogens under International Law and the consequences of its perplexing character in the protection of Human Rights.

\section{I.1. Conceptual Framework}

Some of the central terms used in the formulation of the research questions and objectives deserve a closer look to clarify their intended meaning in this article.

\section{I.1.1. Jus Cogens}

From Latin iūs ("law") and cogēns, from cōgere ("compel"), jus cogens can be rendered by "compelling law" or "peremptory norm". It refers to certain fundamental, overriding principles of International Law, from which no derogation is ever permitted. ${ }^{4}$ In practice, jurists' attempt to classify certain rules, rights and duties as jus cogens

3 E. MULLAH, "International Declaration on Human Rights: Ratification Challenges", available at: http://www.academia.edu , accessed on June 05, 2014.

${ }^{4}$ I., BROWNLIE, Principles of Public International Law, $5^{\text {th }}$ edition, Oxford, 1998, p. 516.

DOI: 10.9790/0837-2108076682 $\quad$ www.iosrjournals.org $67 \mid$ Page


or peremptory norms have not met with success: while there is near-universal agreement for the existence of the category of jus cogens norms, there is far less agreement regarding the actual content of this category. ${ }^{5}$ Examples of jus cogens norms include: "prohibition on the use of force; the law of genocide; principle of racial non-discrimination; crimes against humanity; and the rules prohibiting trade in slaves or human trafficking". ${ }^{6}$ The antonym of jus cogens is Jus dispositivum. This is the law adopted by consent. It is the category of International Law that consists of norms derived from the consent of States. It is founded on the self-interest of the participating States. Jus dispositivum binds only those States consenting to be governed by it. In International Law, there is another term often confused with jus cogens; obligation erga omnes (Latin: "in relation to everyone"). Erga omnes obligations have been referred to by the ICJ in the paragraph 33 of the Barcelona Traction case:

(...) In particular, an essential distinction should be drawn between the obligations of a State towards the international community as a whole, and those arising vis-à-vis another State in the field of diplomatic protection. By their very nature the former are the concern of all States. In view of the importance of the rights involved, all States can be held to have a legal interest in their protection; they are obligations erga omnes. ${ }^{8}$

The legal distinction between jus cogens and obligation erga omnes is not clear enough. Nevertheless, the two concepts are not synonymous. In our humble view, international crimes that rise to the level of jus cogens constitute obligation erga omnes which are non-derogable. Thus, jus cogens refers to the legal status that certain international crimes reach, and obligation erga omnes pertains to the legal implications arising out of a certain crime's characterization as jus cogens. Accordingly, these two concepts are different from each other. ${ }^{9}$ Although Jus cogens are erga omnes obligations, not all erga omnes obligations can be considered as jus cogens. The close link between both of them lays on the fact that jus cogens as primary rules entails some of the common values that erga omnes are aimed to protect. ${ }^{10}$

\section{I.1.1.1. Origin and Features}

From the theoretical point of view, "the concept of jus cogens appeared at the end of $19^{\text {th }}$ century when some authors claimed the possible invalidity of international agreements contrary to certain imperative norms of International Law even if it was not possible to identify those norms". ${ }^{11}$ Accordingly, the definition of the concept of jus cogens emerged in international practice from the work of the International Law Commission devoted to the codification and development of the legal regime of international agreements, which resulted in the signing of the 1961 Vienna Convention on the Law of Treaties. ${ }^{12}$

The article 53 thereof expressly declares void the treaty which, at the time of its conclusion, conflicts with a peremptory norm of General International Law. The wording of this article is as follows:

A treaty is void if, at the time of its conclusion, it conflicts with a peremptory norm of General International Law. For the purposes of the present Convention, a peremptory norm of General International Law is a norm accepted and recognized by the international community of States as a whole as a norm from which no derogation is permitted and which can be modified only by a subsequent norm of General International Law having the same character. ${ }^{13}$

This was the emergence of a legal definition of jus cogens, not the emergence of the concept itself or its legal value, which was elaborated by the international and national Courts. Indeed, the concept of jus cogens existed before the advent of the Vienna Convention: "in the positive Humanitarian Law, the concept was

${ }^{5}$ Idem, p. 517.

${ }^{6}$ A., BÖSL and J., DIESCHO, (eds.), Human Rights in Africa: Legal Perspectives on their Protection and Promotion, 2009, pp. 57-59.

${ }^{7}$ J., P., GRANT and J., CRAIG BARKER, (eds.), Encyclopedic Dictionary of International Law, ( $3^{\text {rd }}$ edition), Oxford University Press, 2009, p. 125.

${ }^{8}$ International Court of Justice, Barcelona Traction Light and Power Company Limited, 1970, paragraph 33.

${ }^{9}$ M. CHERIF BASSIOUNI, International Crimes: Jus Cogens and Obligatio Erga Omnes, De Paul University Press, 1997, p. 34.

10 MONICA M., DIAZ, "Enforcement of International Responsibilities of States", available at: http://trademeetsdevelopment.wordpress.com/tag/ius-cogens/ , accessed on June 23, 2014.

11 C., TOMUSCHAT, J.-M., THOUVENIN, the Fundamental Rules of the International Legal Order: "Jus Cogens" and "Erga Omnes Obligations", Berlin, 2006, p. 83.

12 Vienna Convention on the Law of Treaties, Adopted on 22 May 1969 and opened for signature on 23 May 1969 by the United Nations Conference on the Law of Treaties.

${ }^{13}$ Ibid, article 53. 
already present (...). It resulted from the practices between nations and laws of humanity and conscience". ${ }^{14}$ Though, the issue to know how to recognize a norm as part of jus cogens seems difficult. Basing on the abovementioned article 53, we can at least identify some characteristics. This article emerged three key elements to consider. For the quality of jus cogens, a norm must both: be peremptory (1), belong to the General International Law (2), and nullify treaties adopted in violation of its provisions (3). Below, these three elements are largely analyzed.

\section{I.1.1.1.1. Peremptory Norm}

In general, it is possible for two States to decide, as regards their mutual relations, not to apply certain norms of International Law which impose obligations towards each other, or even to choose to apply other norms other than those provided by General International Law. This is not the case for a jus cogens norm. It is mandatory for all recipients. It is therefore a prohibitive norm constituting an important limitation to the contractual autonomy of the States. ${ }^{15}$ Jus cogens is precisely characterized by the fact that it accepts no derogation in the mutual relations between States. This means that a "State cannot discharge itself from the obligations that a norm of jus cogens imposed, even by a treaty". ${ }^{16}$ It follows from this analysis that "the jus cogens has a prohibitive character, but in a very particular sense, since the scope of this prohibition is to prevent any departure from its provisions". ${ }^{17}$

\section{I.1.1.1.2. Norm of General International Law}

General International Law has been defined by the International Law Commission as: "the set of norms applicable to all member States of the international community, as opposed to international norms for some of them and which constitute the particular International Law, whether regional, local or bilateral." ${ }^{18}$ The Commission places particular emphasis on this point: "the fact that the jus cogens is a norm of General International Law emphasizes, in fact, that it has a universal character". ${ }^{19}$ This feature underlines that the jus cogens is characterized by its importance to the international community as a whole. ${ }^{20}$

\section{I.1.1.1.3. Norm rendering void any derogatory rule}

This is the "essential and exceptional character of jus cogens". ${ }^{21}$ Indeed, the nullity is the worst that can befall a legal act sanction, since removes all legal effects that could normally occur. In International Law, such an effect is extremely rare. The usual sanction of an internationally wrongful act is the involvement of the State responsibility. The strictness of the sanction stems directly from the very fundamental importance of jus cogens norm for the international community. It follows, quite logically, that the States are being placed in the legal impossibility of escaping from its application, since if they try, their actions will not produce legal effects. ${ }^{22}$

\section{I.1.1.2. Development and content}

The 1961 Vienna Convention on the Law of Treaties does not establish specific procedural development of jus cogens. However, "it should be noted that in the process of forming a jus cogens, the

14 RENAUDIN, F., “Jus Cogens and International Law", CNRS, available on: http://www.opuscitatum.com, Accessed on Mai 28, 2014.

${ }^{15}$ L., YEARWOOD, State Accountability for Breaching Jus Cogens Norms, University of Exeter, 2009.

${ }^{16}$ C., FORCESE, "De-immunizing Torture: Reconciling Human Rights and State Immunity" in McGill Law Journal, Vol.52, 2007, p. 127.

${ }^{17}$ H., EGIL, "X-Raying Human Rights: Values and Tradition Under Fire: Counter-Terrorism \& Civil Liberties Conference", in Offerdal Journal of the Institute of Justice and International Studies, Issue $\mathrm{N}^{\mathrm{O}} 3,2003$, March 2003, Central Missouri State University, p. 153.

${ }^{18}$ United Nations, Yearbook of the International Law Commission, Vol. 2, (Documents of the Second Part of the Seventeenth Session and of the Eighteenth Session Including the Reports of the Commission to the General Assembly), New York, 1966, p. 53.

${ }^{19}$ Yearbook of the International Law Commission, Op.cit, p. 58.

${ }^{20}$ UN General Assembly, "Report of the International Law Commission", 23 July 1999, A/54/10, available at: http://www.refworld.org/docid/3ae6af970.html, accessed 7 June 2014.

${ }^{21}$ K. KAWASAKI, "A Brief Note on the Legal Effects of Jus Cogens in International Law", in Hitotsubashi Journal of Law and Politics, $\mathrm{N}^{\mathrm{0}} 34,2006$, pp. 27-43.

${ }^{22}$ A., GREEN, "Expanding Law's Empire: Interpretivism, Morality and the Value of Legality", in European Journal of Legal Studies, Vol. 4, Issue 1, 2011, p. 23. 
presence of opinio juris is required". ${ }^{23}$ Indeed, jus cogens has developed as a natural law concept while being incorporated as part of legal positive and modern International Law. Whether or not synonymous, jus cogens is clearly an attribute of natural law. Natural law is a theory of law that acknowledges unwritten standards of behavior as a primary source of law. Natural law has religious, secular or philosophical sources. ${ }^{24}$

Accordingly, jus cogens norms are the highest rules of International Law, and function essentially as very strong rules of Customary International Law. Customary International Law is the general practice of States which, over a period of time, becomes binding law through repetition and adoption. Therefore, the jus cogens as a Customary International Law is derived from ethical or normative conceptions, representation of international society. ${ }^{25}$ As far as the content of jus cogens is concerned, the Vienna Convention on the Law of Treaties provides no examples of jus cogens and does not specify its content. No list is compiled of jus cogens; it is the case law that erected these peremptory norms. ${ }^{26}$ For instance, in its advisory opinion on reservations to the Convention on the Prevention and Punishment of the Crime of Genocide, the International Court of Justice noted the particular features of the Genocide Convention. For the Court, "the origins of the Convention show that it was the intention of the United Nations to condemn and punish genocide as a crime under International Law."27

Therefore, the jus cogens is a peremptory norm relating to the protection of people's rights. The general opinion of the international community considers that "the prohibition of genocide, torture, apartheid, the use of force and piracy are part of jus cogens". ${ }^{28}$ It should be noted that referring to the content of jus cogens, the International Law Commission for its part, has been limited to a few examples such as: the principle of non-intervention, State sovereignty, respect for given word (pacta sunt servanda), the principle of disputes peaceful settlement, respect for diplomatic and consular law, illegality of genocide, slavery, trafficking and piracy, principle of liability and compensation for damage caused to another, autonomy of the will of States and freedom of contract in accordance with International Law, respect for the minimum standard in the treatment of foreigners. ${ }^{29}$ Accordingly, a significant literature recognizes the following rules as part of jus cogens: "prohibition of use of force, genocide, and crimes against humanity, war crimes, piracy, slavery and practices similar to slavery, torture, the right of people to self-determination, and other fundamental Human Rights". ${ }^{30}$

\section{I.2.1. Vagueness of Jus Cogens}

There is a vast literature about the jus cogens and its importance in the development of International Law. Despite this, there is little consensus on the content and scope of this concept. Many authors maintain its existence, but there is still a hot debate about its content and its application. For instance, to ascertain the vagueness of jus cogens, in his memoire on a "Critical Analysis of the Scope and Application of Jus Cogens", R., V., SARARA concludes that: "(...) its practical application is faced with many challenges due to doctrinal incoherency. The principle seems to be thriving due to its uncertainty and ambiguity". 31

The point is emphasized by A., M., WEISBURD maintaining that "(...) any consideration of the concept of jus cogens is necessarily rather complex". ${ }^{32}$ The author considers the implications of the difficulty in specifying the content of jus cogens, arguing that this problem reveals fundamental theoretical and practical problems with the concept. Toward the last portion of the discussion, he attempts to show that considering the concept of an international jus cogens in light of reasonable criteria of legitimacy exposes both theoretical

${ }^{23}$ S., TALMON, “Jus Cogens after Germany v. Italy: Substantive and Procedural Rules Distinguished", in Leiden Journal of International Law, Vol., 25, Issue 4, December 2012, pp. 979-1002.

${ }^{24}$ K., PARKER, and L., B., NEYLON, “Jus Cogens: Compelling the Law of Human Rights", in Hastings International and Comparative Law Review, Vol.12, 1989, p. 5.

${ }^{25}$ C., TOMUSCHAT, J.-M., THOUVENIN, Op.cit. p. 84.

${ }^{26}$ P. B., STEPHAN VANDERBILT, "The Political Economy of Jus Cogens", in Journal of Transnational Law, Vol. 44, 2011, p. 66.

${ }^{27}$ Reservations to the Convention on Genocide Case (Advisory opinion), ICJ Reports, Vol. 15, 1951, p.23.

${ }^{28}$ S., TALMON, "The Duty Not to 'Recognize as Lawful' a Situation Created by the Illegal Use of Force or Other Serious Breaches of a Jus Cogens Obligation: an Obligation without Real Substance?" in Oxford Legal Studies Research Paper, N . 19, 2006, p. 99.

${ }^{29}$ Draft Articles on the Law of Treaties between States and International Organizations or Between International Organizations with Commentaries, Adopted By the International Law Commission at Its ThirtyFourth Session, in 1982.

${ }^{30}$ M., RWANKUBITO, On the Applicability of the Rules of Public International Law: Myth or Reality? Kigali Independent University, Kigali, 2006, p. 45.

${ }^{31}$ R., V., SARARA, A Critical Analysis of the Scope and Application of Jus Cogens, University of Kent, 2012.

${ }^{32}$ A. M., WEISBURD, Op.cit, p. 12. 
problems and practical difficulties and concludes that "the concept of jus cogens as actually defined can neither make any sense nor serve any useful purpose in the international legal system". 33

Indeed, the existing literature on the topic reflects the ambivalent nature of the jus cogens concept. A significant portion of the writings on this topic criticizes the vagueness ${ }^{34}$, emptiness ${ }^{35}$, uselessness ${ }^{36}$, and potential for political abuse ${ }^{37}$ of the jus cogens concept, as well as the inadequacy of its conceptual bases ${ }^{38}$, thereby challenging the very existence of the notion of jus cogens. Other authors, on the other side, have sought to defend the usefulness of this concept and suggested definitions containing detailed criteria allowing the establishment of the jus cogens character of specific norms. ${ }^{39}$ Again, others implicitly recognize the existence of the jus cogens concept and attempt to determine its nature and particularity within the rules of International Law. ${ }^{40}$ Still, all those academic discussions on jus cogens share a common approach, namely the fact that their criticisms of, support for, and overall analysis of jus cogens invariably relate to the vagueness of this concept. $\mathrm{Be}$ it as it may, this study goes beyond a simple analysis. Apart from confirming the actual vagueness of the concept of jus cogens, it goes further to suggest what to do and by whom to overcome this issue.

\section{CHAPTER II: CLARIFICATION AS A PREREQUISITE FOR JUS COGENS ENFORCEMENT}

Ever since its inclusion in the 1969 Vienna Convention on the Law of Treaties, jus cogens has been a source of controversy. Of particular interest is the debate on the issue of its clear definition and a stabilized referential value. This stabilization might in turn reinforce its meaning and, arguably, the cohesion of the international societal body. But whose task should this be and in which process? The answer to this question and to other similar questions could be discussed in this chapter two. This one will show that if jus cogens has been successful in providing the societal body with a set of identity values, it has dramatically failed to operate as an ordering factor of social practices. The overall objective of this chapter is to wonder why the actual situation of jus cogens is so and to see what can be done (and by whom) to enhance its implementation.

\section{II.1. General critiques on Jus Cogens}

The clarification of the notion of jus cogens in International Law is advancing, but is still far from being completed. The States and the International Court of Justice have been inactive in stating expressly which norms they recognize as peremptory in the present-day International Law. This inactivity and the consequent uncertainty as to which norms are peremptory constitute at present the main problem of the viability of jus cogens. $^{41}$ The concept is accordingly subjected to numerous critics from scholars.

\section{II.1.1. Article 53 of the Vienna Convention is vague}

At the outset, it should be recognized that the 1969 Vienna Convention on the Law of Treaties' definition of jus cogens leaves the meaning of its constituent concepts un-clarified. When can it be said, for example, that a norm exists, as distinct and independent from similar norms? What constitutes acceptance by the international community of States as a whole? Does "international community of States as a whole" mean that the resistance of a single State, for whatever reason, can prevent the coming into being of a new jus cogens norm, or rather, can a convincing, or even simple majority of States suffice to usher in a new norm? Would the answers to these and related questions depend upon the importance of the norm at issue? If so, which criteria; and criteria as made, interpreted, and applied by whom, can assist in determining the importance of such a norm? Without a doubt, the main text that would be helpful in depicting the content or rather scope and

${ }^{33} \mathrm{Ibid}, \mathrm{p} .13$.

${ }^{34}$ G., SCHWARZENBERGER, “International Jus Cogens?” in Text Law Review, Vol., 1965, p. 469.

${ }^{35}$ A. M., WEISBURD, Op.cit. p. 17.

${ }^{36}$ A., D'AMATO, "It's a Bird, It's a Plane, It's Jus Cogens", in Northwestern University School of Law Scholarly Commons: Faculty Working Papers, Paper 61, 1990-1991, p. 6.

${ }^{37}$ G., A., CHRISTENSON, "Jus Cogens: Guarding Interests Fundamental to International Society", in University of Cincinnati College of Law Scholarship and Publications: Faculty Articles and Other Publications, Paper 159, 1987, p. 591.

${ }^{38}$ G. M., DANILENKO, "International Jus Cogens: Issues of Law-Making", in European Journal of International Law, Vol.42, 1991, p. 44.

${ }^{39}$ L., YEARWOOD, “Jus Cogens: Useful Tool or Passing Fancy? A Modest Attempt at Definition”, in British Law Journal, Vol.16, 2006, p. 38.

${ }^{40}$ C., KAHGAN, "Jus Cogens and the Inherent Right to Self-Defense", in International Law Students Association Journal, Issue 3, 1996-1997, p. 767.

${ }^{41}$ L., DUHAIME, “Jus Cogens Legal Definition”, Available at http://www.duhaime.org, accessed on July 2, 2014. 
application of jus cogens would be the Vienna Convention on the Law of Treaties. However, the same is vague and does not in any way mention the words. According to the article 53, a treaty is void if, at the time of its conclusion, it conflicts with a peremptory norm of General International Law. For the purposes of the present Convention, a peremptory norm of General International Law is a norm accepted and recognized by the international community of States as a whole as a norm from which no derogation is permitted and which can be modified only by a subsequent norm of general international law having the same character. ${ }^{42}$

This wording opened up debate and since then the topic has never been put to rest. It is agreed that "there is no acceptable definition of jus cogens and the above has been the subject of multiple interpretations. The legal nature of the said concept remains a subject of debate with all sort of speculation." 43 Scholars have raised several issues with the structuring of this article. First is that "it concentrates on what the peremptory norm does and not what constitutes it". ${ }^{44}$ Article 53 of the Convention defines a jus cogens rule by reference to the consequences deriving from the jus cogens character of a norm, namely the fact that such norm cannot be derogated from and not be superseded by another norm, except for a newly-established jus cogens rule. Such a definition does not offer any useful indication as to the substance of jus cogens. However, it is submitted that: creating a list for all jus cogens norms will be like drawing up a constitution with numerous exemptions. The drafters of the Vienna Convention deliberately omitted an enumeration of jus cogens rules in the Convention itself because of their evolving nature. Subsequently, the enumeration of established norms in a time-fixed treaty might restrict the evolution of other norms into jus cogens. ${ }^{45}$

In our humble view, it is evident that there are international norms undeniably accepted as jus cogens. For instance the international community of States has so unequivocally prescribed the absolute obligation of States not to resort to genocide under any circumstances. Absolutely, the perpetual evolution can't prevent enactment of national and international laws. The enumeration of established norms in a time-fixed treaty is not a restriction of the evolution of other norms into jus cogens but a stabilization of the referential value of jus cogens. The international community of States might state expressly which norms it recognizes as peremptory in the present-day International Law.

\section{II.1.2. Article 53 is largely repetitive and no official examples of Jus Cogens have been provided in the Convention}

Likewise, article 53 is also largely repetitive and against logical rules, as it provides that "a peremptory norm is a norm that is considered as peremptory." No references to specific interests or values of the international community of States such as peace, security, and the protection of Human Rights, for example, are contained in the definition of the 1969 Vienna Convention. Furthermore, even if the International Law Commission's commentary includes a few illustrations of jus cogens norms (unlawful use of force, slavery and piracy) ${ }^{46}$ no official examples of such norms have been provided in the Convention. Besides those examples given in the Law, Commission's commentary do not remove basic interpretive obstacles caused by tautology (a peremptory norm is a norm that is recognized as peremptory) and overall-though deliberate and probably unavoidable-vagueness. The lack of any substance to the concept of jus cogens seriously compromises its relevant and consistent application.

\section{II.1.3. The Mode for acceptance and recognition of Jus Cogens is imprecise}

The norm can only evolve if "accepted and recognized by the international community as a whole". Many have opined that "it requires a majority of States to create the norm as opposed to the entire body of States." ${ }^{47}$ However it is not clear on how this is to be quantified in terms of length of practice and the number of States to be involved. In addition, it is necessary that States accept and recognize a norm in question as peremptory. This requirement is identical to that of opinio juris in the actual formation of custom. It should be

${ }^{42}$ Vienna Convention on the Law of Treaties, Op.cit, article 53.

${ }^{43}$ R., V., SARARA, A Critical Analysis of the Scope and Application of Jus Cogens, University of Kent, (LLM Thesis), January 16, 2012.

${ }^{44}$ A., ORAKHELASHVILI, "The Impact of Peremptory Norms on the Interpretation and Application of United Nations Security Council Resolutions" in the European Journal of International Law, Vol. 16, N.1, 2005.

${ }^{45}$ United Nations Conference on the Law of Treaties, (First Session, Vienna), 26 March-24 May 1968, Official Records, Summary Records of the Plenary Meetings and of the Meetings of the Committee of the Whole, UN Publication, New York, 1969.

${ }^{46}$ Draft Articles on the Law of Treaties with commentaries adopted by the International Law Commission at its eighteenth session, in 1966, and submitted to the General Assembly as a Part of the Commission's Report Covering the Work of that Session, paragraph 38.

${ }^{47}$ R., V., SARARA, Op.cit., p. 34. 
noted that the number of States required for this acceptance to be effective remains controversial. ${ }^{48}$ It appears that jus cogens derives either from general treaties or international custom but the same still remain a mystery. The complication being that "determining opinio juris which is an essential element of evolution of custom remain controversial-what about the consent requirement of jus cogens?"49 The idea is even made more complex as jus cogens has a binding effect to all non-consenting and objecting States and it would mean that the acceptance must entail a vast support if not all the States and not merely a simple majority. ${ }^{50}$

From a theoretical perspective, it remains unclear how the international community lacking any legislative power can accommodate the idea of dominant principles binding all of its members. While in internal legal orders the introduction of peremptory rules binding all subjects of law raises no difficulty, the absence of any international legislature capable of imposing legal rules on the members of the international community is a major obstacle highlighting the tenuous ground for the very existence of international jus cogens, at least in the usual meaning of the term. As a practical matter, there is a growing danger that in the absence of clearly defined procedures for the creation of jus cogens norms, their emergence and subsequent identification may become a matter of conflicting assertions reflecting political preferences of different groups of States. W., P., NAGAN and J., L., ROOT confirm the assertion when they say that "lack of consensus as regards the basic parameters of the law-making process leading to the emergence of jus cogens inevitably opens the door for the political misuse of the concept." ${ }^{51}$ This issue will be largely discussed in the subsequent paragraph.

\section{II.2. Implications of the vagueness of Jus Cogens}

The lack of clarity of the requirement of acceptance by the international community and the more general definitional inadequacy of the jus cogens concept leave vital questions pertaining to its content, sources and formation largely unanswered and pose seemingly insurmountable problems for its application in practice. ${ }^{52}$ Consequently, the concept of jus cogens is under threat and there are many issues in its enforcement.

\section{II.2.1. Concept under threat}

The main implication of the vagueness of jus cogens is that this concept is actually under threat. At such a critical time, one would expect the concept of jus cogens to have been fundamentally called into question by scholars. Early warnings voiced by some commentators about the risk of relativizing normativity left their mark and continue to be quoted mostly to caution against non-observance of jus cogens. ${ }^{53}$ Surely, certain rules commonly thought to enjoy jus cogens status are not treated by States as fundamental in any recognizable sense. ${ }^{54}$ In effect, there have been many cases in the past in which acts supposed to violate jus cogens evoked no effective international response. In those cases, however, "the violations were simply ignored, or attributed to politics, or allowed to fall from public view after drawing condemnatory resolutions in the U.N. General Assembly".55

\section{II.2.2. Issues in Jus Cogens enforcement}

Since World War II, "there has grown an idea that violations of Human Rights cannot go unpunished. In the last two decades, abhorrence of impunity has migrated to the concept of jus cogens. ${ }^{, 56}$ Thus, a robust conception of jus cogens assumes that independent judges and tribunals, informed by the views of non-state actors, can identify core international obligations and manage their tradeoffs with other values pursued by the

48 S., J., CUMMINS, D., P. STEWART, (eds), Digest of United States Practice in International Law, International Law Institute, Washington, 2001.

${ }^{49}$ A., AUST, Modern Treaty Law and Practice, Cambridge University Press, Cambridge, 2000, p. 74.

${ }^{50}$ Ibid., p. 75.

${ }^{51}$ W., P., NAGAN and J., L., ROOT, The Emerging Restrictions on Sovereign Immunity: Peremptory Norms of International Law, the UN Charter, and the Application of Modern Communications Theory, University of Florida, 2012, p. 34.

${ }^{52}$ S., MULLER, S., ZOURIDIS, M., FRISHMAN, (et al.), (Eds), The Law of the Future and the Future of Law, Torkel Opsahl Academic Publisher, Oslo, 2011, p. 514.

53 R., PROVOST, International Human Rights and Humanitarian Law, Cambridge University Press, Cambridge, 2004, p. 127.

${ }^{54}$ R., BECKMAN and D., BUTTE, "Introduction to International Law", available at https://www.ilsa.org, Accessed on July, 08, 2014.

${ }^{55}$ U., LINDERFALK, "The Effect of Jus Cogens Norms: Whoever Opened Pandora's Box, Did You Ever Think About the Consequences?" in European Journal of International Law, Vol. 18, Issue 5, pp. 853-871.

56 P., B., STEPHAN, "The Political Economy of Jus Cogens" in Virginia Public Law and Legal Theory Research Paper, N $\mathrm{N}^{\mathrm{o}}$. 2011-14, March 7, 2011. 
international legal system, and that the actions of independent judges and tribunals, informed by non-state actors, will influence State behavior. Undeniably, as law, jus cogens as in its actual status fails. "Its content is inevitably uncertain; there is total confusion about the sources, and the scope of its application." $" 57$ Taken together, these entire problems hinder the effective enforcement of jus cogens. What is more disastrous is that "the means most often suggested for determining its content lack both the authority and the capability to carry out the task." 58 Then what to do? The answer to this query should be discussed under the subsequent title.

\section{II.3. Actors and ways forward}

The following paragraphs show that there should be three main actors in determining and putting jus cogens into effect. These are United Nations, International Court of Justice and States.

\section{II.3.1. Role of the United Nations}

The United Nations has played a major role in defining, codifying, and expanding the realm of international law-jus cogens being one of its components. ${ }^{59}$ The International Law Commission, established by the General Assembly in 1947, is the primary institution responsible for these activities. The Legal Committee of the General Assembly receives the commission's reports and debates its recommendations; it may then either convene an international conference to draw up formal conventions based on the draft or merely recommend the draft to States. ${ }^{60}$ The International Court of Justice reinforces legal norms through its judgments. Thus, the United Nations was founded not only to save succeeding generations from the scourge of war and to reaffirm faith in fundamental Human Rights, but also to establish conditions under which justice and respect for the obligations arising from treaties and other sources of International Law can be maintained.

For this role to be effective, UN might itself comply with core values established by the international community such as jus cogens norms in its activities. To this end, "in the present international legal order lacking centralized and fully developed judiciary, it is up to the UN Security Council for instance to decide on the form of legal protection to be included in its sanctions regime." 61 By virtue of article 103 of the Charter of the United Nations, "an obligation under the Charter prevails over an obligation arising out of any other international agreement." 62 Since member states agreed to carry out the decisions of the Security Council in article $25^{63}$, this article 103 obligation operates irrespective of any other obligation arising out of other treaties or agreement, even if it is contrary to those of general U.N. obligations. The question, however, is whether a Charter obligation could override an obligation that represents the norm of jus cogens.

In our modest view, the Charter of the United Nations might reflect the jus cogens as obliged by its own fundamental principles. Thus, any decision taken under the Charter should conform itself to the jus cogens. International Law Commission acknowledged that the peremptory norm exists in International Law, which permits no derogation and sets down a general definition of jus cogens. Article 53 of the 1969 Vienna Convention on the Law of Treaties notes that "a treaty is void if, at the time of its conclusion, it conflicts with a peremptory norm of General International Law." Additionally, article 64 of the same Vienna Convention provided that: "if a new peremptory norm of General International Law emerges, any existing treaty in conflict with that norm becomes void and terminable". Thus, the role of the United Nations is also to safeguard the hierarchical norms of International Law. Unless a violation of the principles of the UN Charter has occurred, peace and security can hardly be endangered. The Security Council is the body responsible for protecting such laws, from which infringement may constitute a threat to the peace, a breach of the peace, or an act of aggression. In this sense, the United Nations itself is also under an obligation to follow such legal principles. ${ }^{64}$

57 J., A. GREEN, "Questioning the Peremptory Status of the Prohibition of the Use of Force", in Michigan Journal of International Law, 2011, pp. 215-257.

${ }^{58}$ A., ORFORD, (ed.), International Law and its Others, Cambridge University Press, 2006, p. 87.

59 N., M., SAPUTO, "The Ferrini Doctrine: Abrogating State Immunity from Civil Suit for Jus Cogens Violations", in the University of Miami National Security \& Armed Conflict Law Review, Vol. 2, 2012.

${ }^{60}$ UN Department of Public Information, The United Nations Today, New York, 2008, p. 287.

${ }^{61}$ R., A., WESSEL, "Editorial: The UN, the EU and Jus Cogens", in International Organizations Law Review, Vol.3, 2006, pp. 1-6.

${ }^{62}$ UN Charter, article 103.

${ }^{63}$ UN Charter, article 25.

${ }^{64}$ R. WOLFRUM, "The Attack of September 11, 2001, the Wars against the Taliban and Iraq: Is There a Need to Reconsider International Law on the Recourse to Force and the Rules in Armed Conflict?" in Max Planck Year book of United Nations Law, Vol.7, 2003, pp.1-78.

DOI: 10.9790/0837-2108076682 www.iosrjournals.org
74 | Page 


\section{II.3.2. Role of the International Court of Justice}

The Court mandated to adjudicate on the disputes concerning jus cogens is the International Court of Justice. ${ }^{65}$ The case law of the International Court of Justice represents a major contribution in clarifying and in identifying the content of the jus cogens. As the principal judicial organ of Public International Law, the International Court of Justice contributes to the understanding of the fundamental values of the international community expressed in jus cogens. Judicial decisions as such are not a source of law, but the 'dicta' by the International Court of Justice are unanimously considered as the best formulation of the content of International Law in force. From a General International Law perspective, International Case Law is therefore of the utmost importance in determining the legal framework of jus cogens. ${ }^{66}$

Nevertheless, reading through most judgments, it will be noted that the Court has entertained very few disputes involving the concept. ${ }^{67}$ The ICJ has been very conscious in its usage of the concept and is yet to give a solid determination on the existence and breach of jus cogens. Hence, the International Court of Justice has addressed the issue of jus cogens or related concepts, such as obligations erga omnes in limited contexts closely linked to Humanitarian Law; for instance fundamental Human Rights, the prohibition of the threat or use of force, and the peoples' right to self-determination. ${ }^{68}$

The Court's first reference to the notion of obligation erga omnes was made with regard to the outlawing of genocide. In its Advisory Opinion on Reservations to the Convention on the Prevention and Punishment of the Crime of Genocide of 28 May 1951, the Court highlights the particular nature of this Convention so as to recognize implicitly that the outlawing of genocide represents an obligation erga omnes:

The Convention was manifestly adopted for a purely humanitarian and civilizing purpose. It is indeed difficult to imagine a convention that might have this dual character to a greater degree, since its object on the one hand is to safeguard the very existence of certain human groups and on the other to confirm and endorse the most elementary principles of morality. In such a Convention the contracting States do not have any interest of their own; they merely have, one and all, a common interest, namely, the accomplishment of those high purposes which are the raison d'être of the Convention. ${ }^{69}$

Consequently, in a Convention of this type one cannot speak of individual advantages or disadvantages to States, or of the maintenance of a perfect contractual balance between rights and duties. The high ideals which inspired the Convention provide, by virtue of the common will of the parties, the foundation and measure of all its provisions. ${ }^{70}$ Later, in its Barcelona Traction judgment of 5 February 1970, the Court expressly confirms that the outlawing of genocide is an obligation of this nature and clarifies the general concept of obligation erga omnes. According to the Court:

An essential distinction should be drawn between the obligations of a State towards the international community as a whole, and those arising vis-à-vis another State (...). By their very nature the former are the concern of all States. In view of the importance of the rights involved, all States can be held to have a legal interest in their protection; they are obligations erga omnes. Such obligations derive, for example, in contemporary International Law, from the outlawing of acts of aggression, and of genocide, as also from the principles and rules concerning the basic rights of the human person, including protection from slavery and racial discrimination. ${ }^{71}$

More recently, in the Case Concerning Application of the Convention on the Prevention and Punishment of the Crime of Genocide (Preliminary objections) of 11 July 1996, the Court reiterates its opinion on reservations to the Convention on the Prevention and Punishment of the Crime of Genocide, according to which:

The origins of the Convention show that it was the intention of the United Nations to condemn and punish genocide as a crime under International Law involving a denial of the right of existence of entire human groups, a denial which shocks the conscience of mankind and results in great losses to humanity, and which is contrary

${ }^{65}$ Vienna Convention on the Law of Treaties of 1969, Op.cit., article 66.

${ }^{66}$ N., JAYAWICKRAMA, the Judicial Application of Human Rights Law, National, Regional and International Jurisprudence, Cambridge University Press, 2002, p. 59.

${ }^{67}$ G., ZYBERI, "The Humanitarian Face of the International Court of Justice: Its Contribution to Interpreting and Developing International Human Rights and Humanitarian Law Rules and Principles", Available at http://www.academia.edu/556262/, accessed on July 4, 2014.

68 L., HANNIKAINEN, Peremptory Norms (Jus Cogens) in International Law: Historical Development, Criteria, Present Status, Finnish Lawyers Publication, 1988, p. 700.

${ }^{69}$ Reservations to the Convention on the Prevention and Punishment of the Crime of Genocide, Advisory Opinion, 1951, I.C.J., May 28, 1951.

${ }^{70}$ D., A. DESIERTO, Political Science, Martinus Nijhoff Publishers, 2012, p. 310.

${ }^{71}$ Barcelona Traction, Light and Power Company, Limited, Synopsis1 on 5 February 1970, Judgment (I.C.J. Reports), 1970, p. 3. 
to moral law and to the spirit and aims of the United Nations (...). The first consequence arising from this conception is that the principles underlying the Convention are principles which are recognized by civilized nations as binding on States, even without any conventional obligation. A second consequence is the universal character both of the condemnation of genocide and of the cooperation required in order to liberate mankind from such an odious scourge. ${ }^{72}$

The Court deduces from the object and purposes of the Convention as set out in its opinion of 28 May 1951 that: "the rights and obligations enshrined by the Convention are rights and obligations erga omnes". ${ }^{73}$ On the other hand, to transpose the in-derogability paradigm from the law of treaties into other contexts has proved to be a difficult exercise. The rigidity introduced by the in- derogable character of jus cogens has caused a great deal of reluctance on the part of domestic and international courts to draw mechanical conclusions from the hierarchical superiority of peremptory norms over any other rule of International Law. ${ }^{74}$ This was perhaps the logic of the International Court of Justice (ICJ) to keep quiet about the question of jus cogens. The court was aware of its rigid operating procedures and thus refused to sanction the existence of such a category of norms. ${ }^{75}$ In its 1996 Advisory opinion on the Legality of Use or Threat of Use of Nuclear Weapons, the Court created the cacophonic neologism of "intransgressible principles of Humanitarian Law" to avoid referring to jus cogens. ${ }^{76}$ The fact that the ICJ was never fond of jus cogens a legal category of its own creation is further attested to by the Court's alternative use of the notion of obligations erga omnes. In my humble view, while the two notions may be complementary, they remain distinct, and to consider them as synonyms risks to undermine the legal distinctiveness of each category. Paradoxical consequences were reached in the Advisory Opinion on the Israeli Wall, when the ICJ endorsed the ILC's approach on the consequences of a serious violation of peremptory norms, but took that regime to refer to violations of erga omnes obligations instead. "This unfortunate choice created a great deal of confusion in International Law circles and was probably a reason for the Court to hasten recognition of jus cogens in its subsequent case law." ${ }^{, 78}$ With the same discernment by which the Court had previously avoided taking a stance on jus cogens, the ICJ eventually referred to it in its ruling on jurisdiction and admissibility of the application in the recent case concerning Armed Activities in the Territory of the Congo, between the Democratic Republic of the Congo and Rwanda. The ICJ, in tackling the argument advanced by Congo that the Rwandan reservation to article IX of the Genocide Convention ought to be considered null and void as it was contrary to the peremptory prohibition of genocide, held that "the peremptory character of an international rule may not provide a basis for the jurisdiction of the Court, which is always grounded in the consent of the parties." 79 One may wonder why the Court decided to give express recognition to jus cogens in this particular case. A straightforward answer may be that "the Court was simply answering an argument raised by one of the parties." 80 There may, however, have been more compelling reasons of judicial policy which prompted the Court to do so. This allowed the Court to restore the distinction between obligations erga omnes and peremptory norms as different legal concepts. Also, according to the Court, the concept of jus cogens is not deprived of sense, because at least the prohibition of genocide is recognized as such.

Additional guidance on what may have inspired the Court's acknowledgment could perhaps be provided by Judge Ad Hoc DUGARD's separate opinion. Interestingly enough, Judge DUGARD's analysis focuses on the contextual dimension of jus cogens, devoting one entire section of his opinion to jus cogens in international litigation. Having specified that the "judicial decision is essentially an exercise in choice, given that judges often have to opt for one solution rather than another when authorities are divided" 81 , DUGARD maintains that "judges should be guided in making such choices both by principles identified as propositions that describe rights, and policies, namely propositions that describe goals." ${ }^{, 2}$ With D., G., COSTELLOE, we can say that the promotion of solutions that are consistent with the overall objectives of the international legal order

${ }^{72}$ Preamble to the Convention on the Prevention and Punishment of the Crime of Genocide.

${ }^{73}$ Reservations on the Convention on the Prevention and Punishment of the Crime of Genocide, Advisory Opinion, International Court of Justice, May 28, 1951.

${ }^{74}$ A., BIANCH, Op.cit., p. 46.

${ }^{75}$ B. BROWN, International Human Rights Seminar, Chicago-Kent College of Law, 2013.

${ }^{76}$ Legality of the Threat or Use of Nuclear Weapons, Advisory Opinion, I. C.J. Reports 1996, p. 226.

${ }^{77}$ Legal Consequences of the Construction of a Wullin the Occupied Palestinian Territory, Advisory Opinion, I. C. J. Reports 2004, p. 136.

${ }^{78}$ A., BIANCHI, Op.cit., p. 67.

${ }^{79}$ Armed Activities on the Territory of the Congo (New Application: 2002), (Democratic Republic of the Congo v. Rwanda), Jurisdiction and Admissibility, Judgment, I.C.J. Reports 2006, p. 6.

${ }^{80}$ A. BIANCHI, Op.cit., p. 87.

${ }^{81}$ J. DUGARD, Recognition and the United Nations, 1987, p. 142.

${ }^{82}$ Ibid., p. 143. 
would be important in improving the efficiency and integrity of International Law. The peremptory norms are a combination of principles and policy and are hierarchically superior to other values. ${ }^{83}$ This is because they incarnate the main principles of International Law and legalize the most fundamental objectives of the international community.

\section{II.3.3. Role of States}

Jus cogens impose two foremost responsibilities on all States: duty to respect jus cogens and nonrecognition as lawful a situation created by a serious breach of jus cogens.

\section{II.3.3.1. Duty to respect and obligation of non-recognition}

Jus cogens impose a duty on all States to respect core Human Rights and the international order. In addition, jus cogens norms impose a duty on States to assist those agents of the international order that have a right to seek reparations for jus cogens violations. Specifically, all States might provide a forum for claims based on jus cogens violations, regardless of impediments in municipal law or countervailing international legal principles. $^{84}$

The Articles of the International Law Commission on the Responsibility of States for Internationally Wrongful Acts provide in article 41(2) that: "no State shall recognize as lawful a situation created by a serious breach of an obligation arising under a peremptory norm of General International Law." ${ }^{85}$ In its articles on State Responsibility, the ILC has extended the obligation not to recognize as lawful beyond aggression and the illegal use of force to all situations created by a serious breach of a jus cogens obligation.

However, legal literature has not contributed much to the elucidation of the content of the duty not to recognize as lawful a situation created by a serious breach of a jus cogens obligation. Most authors do not address the question of the content of the duty at all. At this point, I would support G., ABI-SAAB in viewing that "the obligation consists mainly in the non-recognition of what is considered illegal and of its results." ${ }^{86}$ Likewise, a decision by a competent organ of the United Nations may establish legal certainty as to the existence of a serious breach of a jus cogens obligation. But, in the absence of such a decision, States may make their own determination at their own risk. The following chapter focuses on Jus Cogens as a tool for Human Rights protection.

\section{CHAPTER III: JUS COGENS AS A TOOL OF HUMAN RIGHTS PROTECTION}

This chapter should be understood as an examination of the jus cogens influence on effective core Human Rights implementation. Its fundamental starting point is that jus cogens can be a legal exit from the dead-end road in which states are formally taking responsibilities for Human Rights implementation and turn out to be not responsible to anyone in cases when those are violated and justice not satisfied. Indeed, in the current era when gross violations of core Human Rights are obviously justified by State sovereignty, territorial jurisdiction, State internal affairs, and so many other pretexts; supported by case laws and many other legal sources, we are convinced that jus cogens revalorization should strengthen core Human Rights implementation. In our view, jus cogens is a notion of the highest normative, fundamental importance for the community. Defined as such, jus cogens norm has a legal impact that challenges State sovereignty and other similar attributes. It opens a legal avenue for overriding them with the unique aim of making core Human Rights implementation viable.

\section{III.1. Human Rights recognized as Jus Cogens}

As we have seen, in International Law, absolute and non-derogable rights are two separate categories. However, these categories are often conflated and confused. The distinction is extremely important and has a significant impact upon how rights are interpreted and applied. ${ }^{87} \mathrm{Be}$ it as it may, even if the correlation between jus cogens and Human Rights was already elaborated, the question to know exactly which Human Rights can

${ }^{83}$ D., G. COSTELlOE, "Political Constructivism and Reasoning about Peremptory Norms of International Law", (2011), Available at: http://digitalcommons.law.wustl.edu, accessed on July 4, 2014.

${ }^{84}$ J., M., BENEYTO, Accountability of International Organizations for Human Rights Violations, (Report), Committee on Legal Affairs and Human Rights, December 2013, p. 47.

${ }^{85}$ International Law Commission, Draft Articles on Responsibility of States for Internationally Wrongful Acts, (November 2001), Available at: http://www.refworld.org/docid/3ddb8f804.html, accessed 3 July 2014.

${ }^{86}$ G., ABI-SAAB, Cited by J., WEILER, A., CASSESE, M., SPINEDI, (et al.), International Crimes of State: A Critical Analysis of the ILC's Draft Article on State Responsibility, 1989, p. 316.

87 R., BALL, "Absolute and No-derogable Rights in International Law", (21 July 2011), available at http://www.parliament.vic.gov.au, accessed on July 18, 2014. 
be invoked as jus cogens, or more precisely: which Human Rights are already jus cogens and which are emerging as jus cogens norms remain; the scholarship being divided on this issue. In my humble view, this question is far from being answered, jus cogens concept being vague itself.

For instance, Judge TANAKA considers the whole of Human Rights as Jus Cogens. He confirms that in these terms: "(...) surely the law concerning the protection of Human Rights may be considered to belong to the jus cogens." "88 On the other side, Judge AMMOUN called the protection of Human Rights "an obligatory legal norm" and insisted that "Human Rights principles appearing in the preamble of the United Nations Charter are jus cogens." ${ }^{89}$ Scholar L., JOHN agrees with him and notes that:

The Charter's basic Human Rights provisions constitute jus cogens. The Universal Declaration of Human Rights is the authoritative interpretation of Human Rights provisions of the United Nations Charter. The Universal Declaration as a whole is itself Customary International Law, and is rapidly establishing itself as jus cogens (Elements of Articles 2(1) and (26). ${ }^{90}$

Finally, analyzing the international treaties, F., F., MARTIN gives a list of Human Rights norms being or becoming jus cogens. His examination is based on the clauses of Human Rights treaties that identify certain Human Rights which may not be derogated from even in time of war or other public emergency. Apart from mentioning the existing or emerging global jus cogens obligations, he also refers to regional jus cogens which, in his view includes the following: "freedom from arbitrary detention; rights of the family; the right to a name; rights of the child; the right to nationality; and the right to participate in government." ${ }^{91}$ In our humble view, the norms enlisted are non-derogable norms, as stipulated by the treaties' provisions. However, this does not make them peremptory norms stricto sensu. We should rather treat the list given above as a list of Human Rights which might obtain compelling character by the nature of rights and duties they contain and by the general acceptance of the treaties in which these Human Rights are stipulated.

Furthermore, a jus cogens has to be articulated by legitimate judicial instances. ${ }^{92}$ Certainly, not all commentators agree on the idea that the whole of Human Rights law presently constitutes imperative rules of jus cogens or on a certain given list of these rights.

\section{III.2. Current gap and obstacles in peremptory Human Rights protection}

As we have seen previously, there are many gaps in peremptory Human Rights protection. First of all, the vagueness of jus cogens hinders the effective implementation of peremptory Human Rights that it protects and this could be seen as a definitional gap. Apart from this, peremptory Human Rights face an implementation gap, as there is lack of practical actions to realize peremptory Human Rights expressed in many international treaties. To this, one could add another gap related to the monitoring issue; since there is lack of special monitoring of how peremptory Human Rights are being protected. Finally, peremptory Human Rights face a normative gap. There is lack of protection against some particular States doctrines that violate peremptory Human Rights. As we have seen, some States doctrines, practices or attributes, such as State sovereignty impede effective Human Rights implementation. That is where the problem of peremptory Human Rights implementation lies: differences in Human Rights standards reflect the differences of the State building process across the world, different judicial systems, law enforcement mechanisms, Human Rights awareness, etc.

\section{III.3. Impact of Jus Cogens on core Human Rights protection}

This is exactly the starting point of our argumentation: core Human Rights enforcement can be advanced through the concept of jus cogens, immune to the barrier of State sovereignty and its other attributes. Most areas of core Human Rights concern are governed by jus cogens. "One way to enhance protection of core Human Rights in domestic actions is to incorporate jus cogens, because jus cogens norms exist and are enforceable independently of treaties, and are immune from many judicial doctrines that have

${ }^{88}$ TANAKA dissenting opinion in South West Africa Cases, Second Phase, Cited by M., GUSTAVO and K., MARTINUS , Promoting Justice, Human Rights and conflict Resolution through International Law, Nijhoff Publishers, 2007, p. 43.

${ }^{89}$ Judge AMMOUN cited by C., J. TAMS, Enforcing Obligations Erga Omnes in International Law, Cambridge University Press, December 1, 2005, p. 65.

${ }^{90}$ Hastings College of the Law, Hastings International and Comparative Law Review, Vol. 12, University of California, 24 Jun 2011, Available at http://books.google.rw/books, accessed on July 18, 2014.

${ }^{91}$ F., F., MARTIN cited by P., ZENOVIĆ, Op.cit, p. 54.

92 A., HALL, "The Challenges to State Sovereignty from the Promotion of Human Rights", (November 17, 2010, Available at http://www.e-ir.info, accessed on July 18, 2014. 
frustrated redress." 93 The concept of jus cogens can judicially and operationally give a legitimate and legal way of core Human Rights enforcement outside any boundary. Jus cogens is not a norm that every single State has to voluntarily accept as a legal norm, it is a result of a sophisticated International Law development in which State attributes are not the highest values. It opens a new dimension of Human Rights enforcement, contrasting the old conception of State and its attributes. ${ }^{94}$

\section{III.3.1. Enhanced judicial protection of individual rights}

The idea that the concept of jus cogens essentially aims to protect individual rights has progressively found acceptance among scholars. Academic writings on jus cogens have increasingly focused on the protection of specific individual rights, ${ }^{95}$ or Human Rights more generally. ${ }^{96}$ The recognition of individual rights as fundamental values of the international legal system and the resulting idea of the existence of a hierarchy of International Law norms inescapably lead to the necessity of providing for heightened protection of those rights. ${ }^{97}$ Due to its deterring effect, the most significant feature of such protection consists of the possibility to prosecute and try authors of international crimes. Significantly, it must be noted that, to some extent, the punishment of international crimes has taken place without, and even against, the will of the States concerned.

\section{III.3.2. Jus Cogens avoids judicial doctrines}

The use of jus cogens can help relieve plaintiffs' burden of overcoming judicial doctrines that have previously appeared to be insurmountable barriers to Human Rights actions. Among these are the: act of State doctrine; political question doctrine; various treaty doctrines such as the self-execution doctrine and the last in time rule; and the requirements for standing.

\section{III.3.2.1. Jus Cogens precludes the act of State doctrine}

The act of State doctrine, articulated in Underhill v. Hernandez ${ }^{98}$, requires courts of one nation to refrain from ruling on or providing relief for acts done by another nation in its own territory. The act of State doctrine has its basis in the idea of sovereignty of nations and international comity. Many victims of Human Rights abuses, however, are unable to seek relief in their own country, even when the act contravenes jus cogens. Thus the act of State doctrine could serve to bar effective remedy anywhere. ${ }^{99}$

\section{III.3.2.2. Jus Cogens avoids the political question doctrine}

A claim based on a jus cogens rule is justiciable and avoids the barrier of the political question doctrine because jus cogens norms are mandatory and do not allow courts to decline judicial review. "The political question doctrine requires judicial abstention in cases raising issues more properly resolved by the executive or legislative branches of government."100 In my modest view, Jus cogens is ipso facto a legal and not political concept. Therefore no policy has the power to violate it. Even in exceptional circumstances (security, war), it cannot be derogated.

\section{III.3.2.3. Jus Cogens avoids the self-execution doctrine}

The self-execution doctrine requires that "treaties (or clauses of treaties) operate of themselves, without the aid of any legislative provisions for them to be justiciable." ${ }^{\prime 101}$ A claim based on a jus cogens violation is actionable independently of a treaty. It is therefore irrelevant whether the government in

93 C., KAUFMANN, Constitutional, Administrative, Economic and Human Rights Law, (Documentation to the Lecture), Law Institute, Fall Term 2010.

${ }^{94}$ S., MULLER, S., ZOURIDIS, M., FRISHMAN, (et al.), (eds), Op.cit., p. 54.

95 S., L., WILLIAMS, "The Illegality of Torture as a Violation of Jus Cogens Norms under Customary International Law”, in Miami International \& Comparative Law Review, VoL. 12, 2004), p. 301.

${ }^{96}$ P., J., STEPHENS, Op.cit., p. 12.

${ }^{97}$ K., G., YOUNG, "The Minimum Core of Economic and Social Rights: A Concept in Search of Content", in the Yale Journal of International Law, Vol. 33, 2013, p. 113.

${ }^{98}$ Underhill v. Hernandez, U.S. Supreme Court, 168 U.S. 250 (1897) 168 U.S. 250, N. 36, November 29, 1897.

99 G. M., ZIMAN, Holding Foreign Governments Accountable for their Human Rights Abuses: A Proposed Amendment to the Foreign Sovereign Immunities Act of 1976, Los Angeles International \& Comparative Law Review, 1999, p.185, available at: http://digitalcommons.lmu.edu/ilr/vol21/iss1/10, July 18, 2014.

${ }^{100}$ N., J., KLEINMAN, "The Act of State Doctrine: From Abstention to Activism", in Journal of International Law, $\mathrm{N}^{\mathrm{o}} 6$, p.115, 2012, available at: http://scholarship.law.upenn.edu/jil/vol6/iss2/1, July 18, 2014.

${ }^{101}$ C., M., VÁZQUEZ, "The Four Doctrines of Self-Executing Treaties", in Georgetown Public Law and Legal Theory Research Paper, $\mathrm{N}^{\mathrm{o}}$. 12, Issue101, Vol. 89, 1995, pp. 695-723.

DOI: $10.9790 / 0837-2108076682 \quad$ www.iosrjournals.org $\quad 79 \mid$ Page


question has ratified a particular treaty, whether the treaty is self-executing or not or whether there is implementing legislation.

\section{III.3.3. Jus Cogens provides standing}

The harm caused by violations of jus cogens affect all persons, whether actual victims, or incidental ones. Because all persons are harmed, each should have standing to bring a suit for redress. The standing requirement, as used in United States courts, has clearly frustrated attempts to remedy alleged Human Rights violations. Direct victims of a violation of jus cogens are often not in a position to bring suit themselves, and must rely on third parties to seek judicial relief. Such was the case in Haitian Refugee Center v. Gracey ${ }^{102}$; where the direct victims of the United States' interdiction program had been forcibly repatriated to Haiti and were not able to bring an action in any court themselves.

\section{III.3.4. Jus Cogens allows for universal jurisdiction}

Jus cogens norms naturally call for universal jurisdiction for their enforcement: violations of jus cogens norms disrupt international order, and thus affect all States and persons. ${ }^{103}$ Since jus cogens obligations transcend national boundaries, jurisdiction over violations of these international standards must be universal. Universal jurisdiction is a prominent part of other international treaties codifying peremptory Human Rights. For example, the Apartheid Convention provides that "violators can be tried in a domestic tribunal of any State party or by an International Penal Tribunal."104 The term "universal jurisdiction" refers to jurisdiction established over a crime without reference to the place of perpetration, the nationality of the suspect or the victim or any other recognized linking point between the crime and the prosecuting State. Actually, it is a principle of jurisdiction limited to specific crimes such as those which are committed against jus cogens norms.

\section{GENERAL CONCLUSION}

A plethora of literature has been written on the topic of jus cogens as a legal concept and its significance in the development of International Law. Despite much time, ink and paper having been devoted to this study, there is little consensus on the content and the scope of Jus Cogens. Its practical usefulness has been burdened by lack of a clear definition, lack of a procedure for its determination and doctrinal weaknesses, as it has been shown throughout this work. Even though scholars agree that there exists in the international community a set of norms the violation of which renders all treaties void, such norms are not easily identified and in the absence of State practice everything has been left to speculation. Likewise, due to its conceptual and theoretical defects, jus cogens has had a limited impact on the actual practice of International Law and its application has been highly controversial. With the ICJ taking a peripheral role, fundamental questions raised remain unanswered. None of the scholars dare to give unchallenged answers to these questions, and we wait on the ICJ, in the case before it, to clarify the pertinent issues.

Accordingly, in this paper, we attempted to show the existing reckless and ambiguous position of the Court regarding the clarification and strengthening the normative basis of jus cogens. Indeed, in any case, up to now, the Court has not shown much familiarity with jus cogens; it has taken more than six decades for it to acknowledge its existence, in spite of its being one of the central features of contemporary International Law. The Court did not lay the procedure for determination of subsequent norms making one to believe that jus cogens is just left to operate on trial and error. There is no documented case where the ICJ has declared that an international treaty was void for being inconsistent with a peremptory norm of International Law. This lack of stability of ICJ in this area is a significant concern of other courts called upon by lawyers to incorporate jus cogens in their rationale decindendi. Definitively, the uncertainties regarding the clear definition and content of jus cogens, which create a risk of unpredictable, incoherent and arbitrary decisions, explain the reluctance of international tribunals to apply this concept. Hence, at the end of this chapter, we can definitely confirm the

\footnotetext{
${ }^{102}$ Haitian Refugee Center, et al., Appellants v. James S. GRACEY, Admiral/Commandant, United States Coast Guard, et al. $\mathrm{N}^{\mathrm{o}}$. 85-5258. United States Court of Appeals, District of Columbia Circuit argued February 25, 1986, decided on January 9, 1987, as amended January 9, 1987.

${ }^{103}$ K. LEE BOYD, "Universal Jurisdiction and Structural Reasonableness", in Texas International Law Journal, VOL. 40, Issue1, 2004, p. 3.

${ }^{104}$ International Convention on the Suppression and Punishment of the Crime of Apartheid, adopted by the GA of the United Nations on 30 November 1973.
} 
hypothesis that clarification is a pre-requisite for effective jus cogens enforcement, and this significant task is attributable to the International Court of Justice.

We especially want to reiterate our confidence in the international community of States as a whole. The consequences of genocide and other crimes against humanity committed over the world in recent years should offer the opportunity to announce a qualitative change in words and actions. States should therefore take into account the importance of compliance with jus cogens and be aware of its role in effective core Human Rights protection. States might therefore respect jus cogens and not recognize as lawful a situation created by its serious breach.

We acknowledge that it would be difficult to achieve a consensus at the jus cogens in its actual status. However, the difficulty is not undefeatable. We humbly suggest its urgent redefinition by the International Court of Justice. If all these suggestions are implemented, we believe the concerns regarding the violation of core Human Rights would be minimized and the doctrine of jus cogens would be generally accepted, as there is no doubt that the doctrine is necessary in today's world.To conclude the present study, we recognize that all aspects of this subject may not have been to explored. The added value from other researchers may be of valuable importance so that the jus cogens is sufficiently and increasingly clarified for its effective role in protecting core Human Rights. Particularly, we wish to suggest that further research in this area should analyze how a specialized international organ could be created to punish jus cogens violations and monitor how peremptory Human Rights are especially being protected.

\section{International conventions}

\section{BIBLIOGRAPHY}

[1] Declaration on the Rights of Persons Belonging to National or Ethnic, Religious and Linguistic Minorities, Adopted by GA Resolution 47/135 of 18 December 1992.

[2] International Convention on the Suppression and Punishment of the Crime of Apartheid, Adopted by the GA of the United Nations on 30 November 1973.

[3] International Covenant on Civil and Political Rights, Adopted by the General Assembly of the United Nations on 19 December 1966.

[4] First Protocol Additional to the Geneva Conventions of 12 August 1949, relating to the Protection of Victims of International Armed Conflicts (A.P. I), 8 June 1977.

[5] Statute of the International Criminal Court, Adopted by the United Nations Diplomatic Conference of Plenipotentiaries on the Establishment of an International Criminal Court on 17 July 1998, Entry into force: 1 July 2002.

[6] Universal Declaration of Human Rights (UDHR), Adopted by the United Nations General Assembly Pursuing its Resolution 217 A (III), Paris, on 10 December 1948.

[7] Vienna Convention on the Law of Treaties, Adopted on 22 May 1969 and opened for signature on 23 May 1969 by the United Nations Conference on the Law of Treaties.

[8]

\section{BOOKS}

[9] AUST A. Modern Treaty Law and Practice (Cambridge University Press, Cambridge 2000).

[10] BALL R. Absolute and Non-Derogable Rights in International Law (Human Rights Law Centre, Sydney 2011).

[11] BESSON S. \& TASIOULAS, J. The Philosophy of International Law (Oxford University Press, New York 2010).

[12] BROWNLIE I. Principles of Public International Law, $5^{\text {th }}$ edition (Oxford University Press, Oxford 1998).

[13] DJEFFAL C. \& KLEIN P. (Eds) The Vienna Conventions on the Law of Treaties: a Commentary (Oxford University Press, Oxford 2011).

[14] JHOFFMANN \& NOLLKAEMPER A. (Eds) Responsibility to Protect: From Principle to Practice (Amsterdam University Press, Amsterdam 2012).

[15] TAMS C.J. Enforcing Obligations Erga Omnes in International Law (Cambridge University Press, Cambridge 2005).

\section{Case law}

[16] Application of the Convention on the Prevention and Punishment of the Crime of Genocide, (Bosnia and Herzegovina v. Yugoslavia), Preliminary Objections, Judgment, I. C. J. Reports 1996.

[17] Armed Activities on the Territory of the Congo (New Application: 2002), (DRC v. Rwanda), Jurisdiction and Admissibility, Judgment, I.C.J. Reports 2006.

[18] Case Concerning East Timor (Portugal v. Australia), International Court of Justice, Reports, General List No. 84 of 30 June 1995.

[19] Certain Expenses of the United Nations, Advisory Opinion, 1962 I.C.J. 151. 


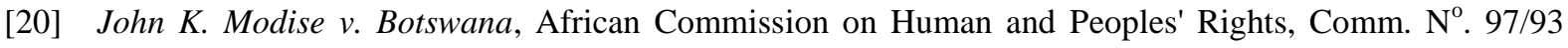
(2000).

[21] Legal Consequences for States of the Continued Presence of South Africa in Namibia (South West Africa) notwithstanding Security Council Resolution 276 (1970), Advisory Opinion, I.C.J. Reports 1971.

[22] Prosecutor v. Tadic, Judgment, ICTY Appeals Chamber \{Case No. IT-94-1-A\}, 15 July 1999.

Journals

[23] BULTZ, A., "Redefining Apartheid in International Criminal Law", in Criminal Law Forum, Vol., 24, Issue 2, June 2013.

[24] COSTEllOE, D., G., "Political Constructivism and Reasoning about Peremptory Norms of International Law", in Washington University Jurisprudence Review, Vol., 4, Issue1, 2011.

[25] GREEN, J., A. "Questioning the Peremptory Status of the Prohibition of the Use of Force", in Michigan Journal of International Law, 2011.

[26] HOSSAIN, K., "The Concept of Jus Cogens and the Obligation Under The U.N. Charter", in Santa Clara Journal of International Law, Vol. 3, Issue 1, 2005.

[27] KAREN, P., "Jus Cogens: Compelling the Law of Human Rights", in Hastings International and Comparative Law Review, Vol.12, 1988-1989.

[28] KAWASAKI, K. "A Brief Note on the Legal Effects of Jus Cogens in International Law", in Hitotsubashi Journal of Law and Politics, $\mathrm{N}^{\mathrm{0}} 34,2006$.

[29] MARTENCZUK, B., "the Security Council, the International Court and Judicial Review: What Lessons from Lockerbie?" in EJIL, Vol., 10, Issue 3, 2012.

[30] SAUL, M., "the Normative Status of Self-Determination in International Law: A Formula for Uncertainty in the Scope and Content of the Right?" in Human Rights Law Review, Vol. 11, Issue 4, Oxford University Press, 2011.

[31] SCOBBIE, I., "The Invocation of Responsibility for the Breach of Obligations under Peremptory Norms of General International Law” in EJIL, Vol. 13 No. 5, 2002.

Reports

[32] AMNESTY INTERNATIONAL, "Report 2009: The State of the World's Human Rights", in Amnesty International Publications, 2009.

[33] BENEYTO, J., M., Accountability of International Organizations for Human Rights Violations, (Report), Committee on Legal Affairs and Human Rights, Dec., 2013.

[34] ESPIELL, H., G., (Special Rapporteur), Implementation of United Nations Resolutions Relating to the Right of Peoples Under Colonial and Alien Domination to Self-Determination, Commission of Human Rights, Vol.1, 20 June 1978.

[35] HUMAN RIGHTS COUNCIL, Human Rights Situation that Require the Council's Attention: Report of the International Commission of Inquiry on Libya, Nineteenth Session, Agenda item 4, Document $\mathrm{N}^{\mathrm{O}}$ A/HRC/17/44, 8 March 2012.

[36] UNITED NATIONS, Report of the $1^{\text {st }}$ UN Special Rapporteur on Torture, UN Documents no E/CN.4/ 1986/15, 19 February 1986.

[37] UNITED NATIONS, Report of the International Law Commission, Fifty-sixth Session, 3 May-4 June and 5 July-6 August 2004, New York, 2004.

[38] UNITED NATIONS, United Nations Conference on the Law of Treaties, (First Session, Vienna), 26 March-24 May 1968, Official Records, Summary Records of the Plenary Meetings and of the Meetings of The Committee of the Whole, UN publication, New York, 1969.

Electronic sources

[39] BALL, R., "Absolute and no-derogable rights in International Law", (21 July 2011), available at: http://www.parliament.vic.gov, accessed on July 18, 2014.

[40] BARNIDGE, R., P., "Questioning the Legitimacy of Jus Cogens in the Global Legal Order", available at: http://www.academia.edu, accessed on July 4, 2014.

[41] COSTELlOE, D., G. "Political Constructivism and Reasoning about Peremptory Norms of International Law", available at: http://digitalcommons.law.wustl.edu, accessed on July 4, 2014.

[42] DUHAIME, L., “Jus Cogens Legal Definition”, available at: http, accessed on July 2, 2014.

[43] HALL, A., "The Challenges to State Sovereignty from the Promotion of Human Rights", (November 17, 2010, available at http://www.e-ir.info, July 18, 2014.

[44] RENAUDIN, F., “Jus Cogens and International Law”, CNRS, available at: http://www.opuscitatum.com, accessed on May 28, 2014.

[45] SHELTON, D., "Protecting Human Rights in a Globalized World", available at: http://www.bc.edu, accessed on June 13, 2014.

[46] STEPHENS, P., J., "A Categorical Approach to Human Rights Claims: Jus Cogens as a Limitation on Enforcement?", available at: http://hosted.law.wisc.edu, July 4, 2014. 